\title{
INTERNAL TRANSCRIBED SPACER SEQUENCES ANALYSIS OF GENETIC VARIATION AMONG AND WITHIN POPULATIONS OF ATRIPLEX HALIMUS FROM DIFFERENT BIOCLIMATIC ZONES IN MOROCCO
}

\author{
S. Bouda ${ }^{1 *}$, L. E. Hernandez ${ }^{2}$ and A. Haddioui ${ }^{1}$ \\ ${ }^{1}$ Laboratory of Biotechnologies and Valorization of Plant Genetic Resources \\ Faculty of Sciences and Techniques, Sultan Moulay Slimane University \\ P. B. 523, Beni Mellal, Morocco; *E-mails: saidbouda@yahoo.fr, s.bouda@usms.ac.ma \\ ${ }^{2}$ Laboratorio de Fisiología Vegetal, Departamento de Biología, Universidad Autónoma de Madrid \\ Campus de Cantoblanco, 28049 Madrid, España
}

(Received: 08 November, 2018; Accepted: 22 March, 2019)

The genetic diversity of 12 Atriplex halimus L. populations collected throughout its natural range in Morocco has been studied by using sequences of nrDNA ITS region. Within-population genetic diversity was high in comparison to others species with similar life histories and ecological traits. Most of genetic variation detected by AMOVA resided within populations $(94 \%)$, relative to the amount of variation among populations $(6 \%)$. The level of populations differentiation $\left(\mathrm{F}_{\mathrm{ST}}=0.06\right)$ was low, which corresponds with the high level of gene flow (4.00) revealed between populations. Differentiation among ecological groups of populations accounted only for $1.23 \%$ of the total ITS variation, which indicates that climatic conditions did not have an effect of population's structuration or that this differentiation is obviously not related to ITS markers. Furthermore, very low genetic differentiation $\left(\mathrm{F}_{\mathrm{CT}}\right.$ $=0.015$ ) was observed between regions (Moroccan populations versus American population). Strangely enough, geographic distances were not correlated to genetic differentiation between the populations $(\mathrm{r}=0.06, \mathrm{P}=0.5)$. The structuration of populations in five groups was not operated according to their bioclimatic type. The data obtained in this assay could play a crucial role to establish efficient strategies for genetic resources conservation and to work out the scheme of breeding programs of Atriplex.

Key words: AMOVA, Atriplex halimus, gene flow, genetic variability, ITS sequences, natural population

\section{INTRODUCTION}

The saltbush Atriplex halimus L., a chenopodiaceous, is a $\mathrm{C}_{4}$ monoecious spontaneous perennial shrub of the arid and semi-arid Mediterranean regions. Owing to its tolerance to environmental stresses and its use as a fodder shrub for livestock in low rainfall areas (Le Houérou 1992), Atriplex halimus is the most planted native species of fodder trees and shrubs in West Asia and Nord Africa (Le Houérou 2000). Atriplex halimus was used, also, as a promising species for the reclamation of degraded lands where excessive salinity 
and low moisture level are the main factors limiting plants growth, but where there is also a need for animal forages (Bouda et al. 2008). In Morocco, A. halimus L. is widely distributed as a wild species, particularly in habitats that combine relatively high soil salinity with aridity. The species is using as excellent livestock fodder because of its favourable crude protein content and also as a mean of soil erosion control in depleted rangelands and dust mining (Boulanouar 1996).

The analysis of genetic variability within and among populations over the geographical range of the species, based on molecular markers, can minimise future risk of genetic erosion, establish forms of rational economic exploitation, and assist in the development of pertinent conservation and genetic improvement strategies (Reis 1996). Studies of population genetic structure provide windows to the roles that the fundamental evolutionary forces of selection, gene flow, and drift play in processes such as local adaptation and speciation (Foster et al. 1998, Slatkin 1994).

Genetic research on Atriplex halimus has received little attention. This is unfortunately due to their modest economic value generally attributed to shrubby species, which are not yet seriously considered as cultivated species (Stringi et al. 1994). Nevertheless, in the last two decades, with climate changes and the resulting threats to the survival plant populations, substantial works have been devoted to study the genetic diversity of Atriplex halimus (Bouda et al. 2008, 2013, El Ferchichi et al. 2006, Elframawy et al. 2016, Haddioui and Baaziz 2001, Hcini et al. 2006, 2007, Ortíz-Dorda et al. 2005, Walker et al. 2005, $\mathrm{Zhu}$ et al. 2001). It seems that there is a large genetic variability in Atriplex halimus populations of different Mediterranean origins and such heterogeneity could be exploited to develop adequate populations with a combination of good traits such as high adaptability to limiting factors in arid and semi-arid Mediterranean environments. Populations of Atriplex halimus are located in ecologically very different habitats (Le Houérou 2000), which differ to high degree from each other with regard to ecological factors such as nutrients, light and water, just as in the type of land use by grazing or mowing. Ecological differences among the habitats colonised by a plant species can result in development of ecotypes (Gunter et al. 1996).

In the present study, we used the nucleotide sequences of entire ITS region of ribosomal DNA to analyse the genetic variability of natural populations of A. halimus from different bioclimatic type. Furthermore, by using the AMOVA approach we look for the amount of variation residing between ecological and regional groups of populations. 


\section{MATERIALS AND METHODS}

\section{Plant material}

Twelve populations of Atriplex halimus were analysed; 11 natural populations from Morocco and a 21-year-old Moroccan plantation stemmed from Wyoming, USA (Table 1, Fig. 1). Seven individuals were collected randomly from each of 11 populations of A. halimus through its geographical range in Morocco, and they were stored at $-80{ }^{\circ} \mathrm{C}$ until DNA extraction. They correspond to three climatic contexts: semi-arid zones (Settat, Sidi Bouzid and Essouiria populations), arid zones (Kelaâ des Sraghna, Marrakech, Chichaoua, Tafraout and Wyoming (USA) populations), and Saharan zones (Ouarzazate, Laâyoune, Es Semara and Dakhla populations). The plants of the American population were collected from Centre de Production des Semences Pastorales (CPSP) orchard in Kmiss M'touh, El Jadida, Morocco, where the stock plants have been kept in soil since 1985 .

\section{DNA extraction and $P C R$ reactions}

Genomic DNA from leaves was extracted with Nucleon Phytopure DNA extraction kit following the manufacturer's instructions. DNA concentration

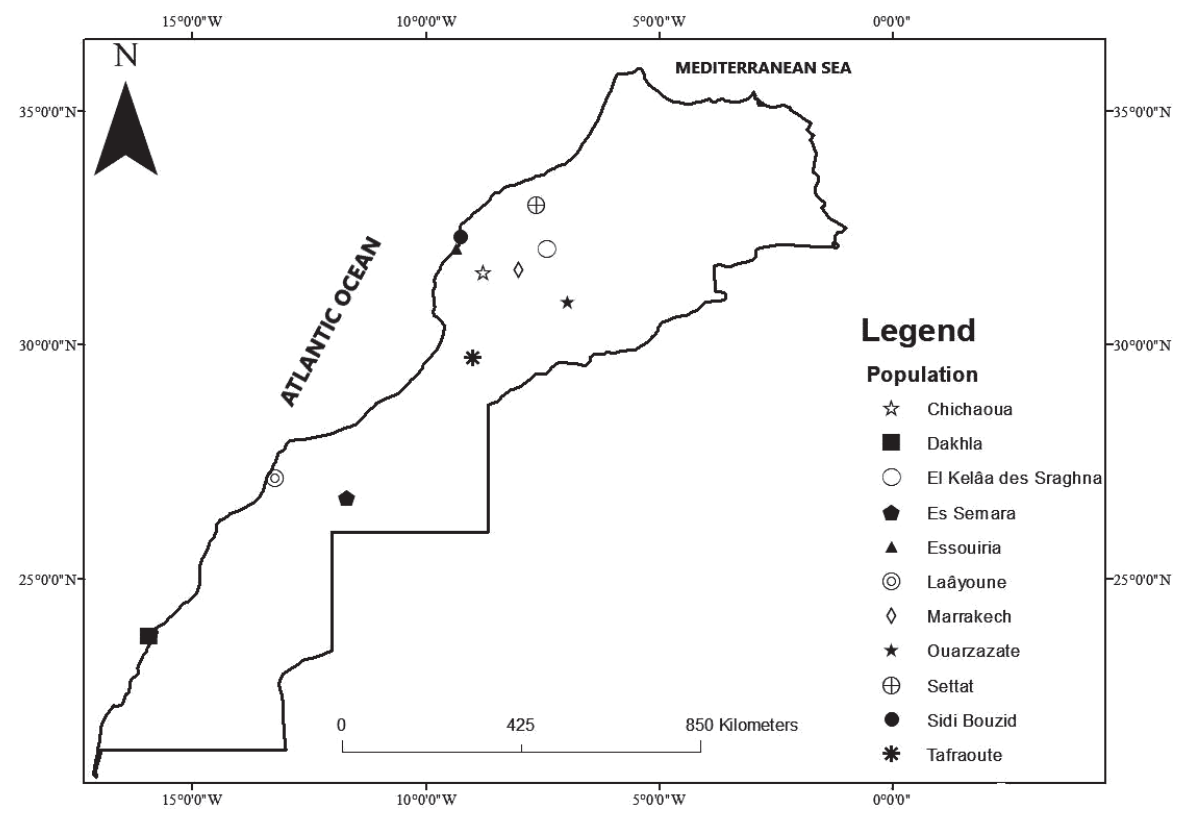

Fig. 1. Map of Morocco showing the localities of Atriplex halimus populations analysed in this study 


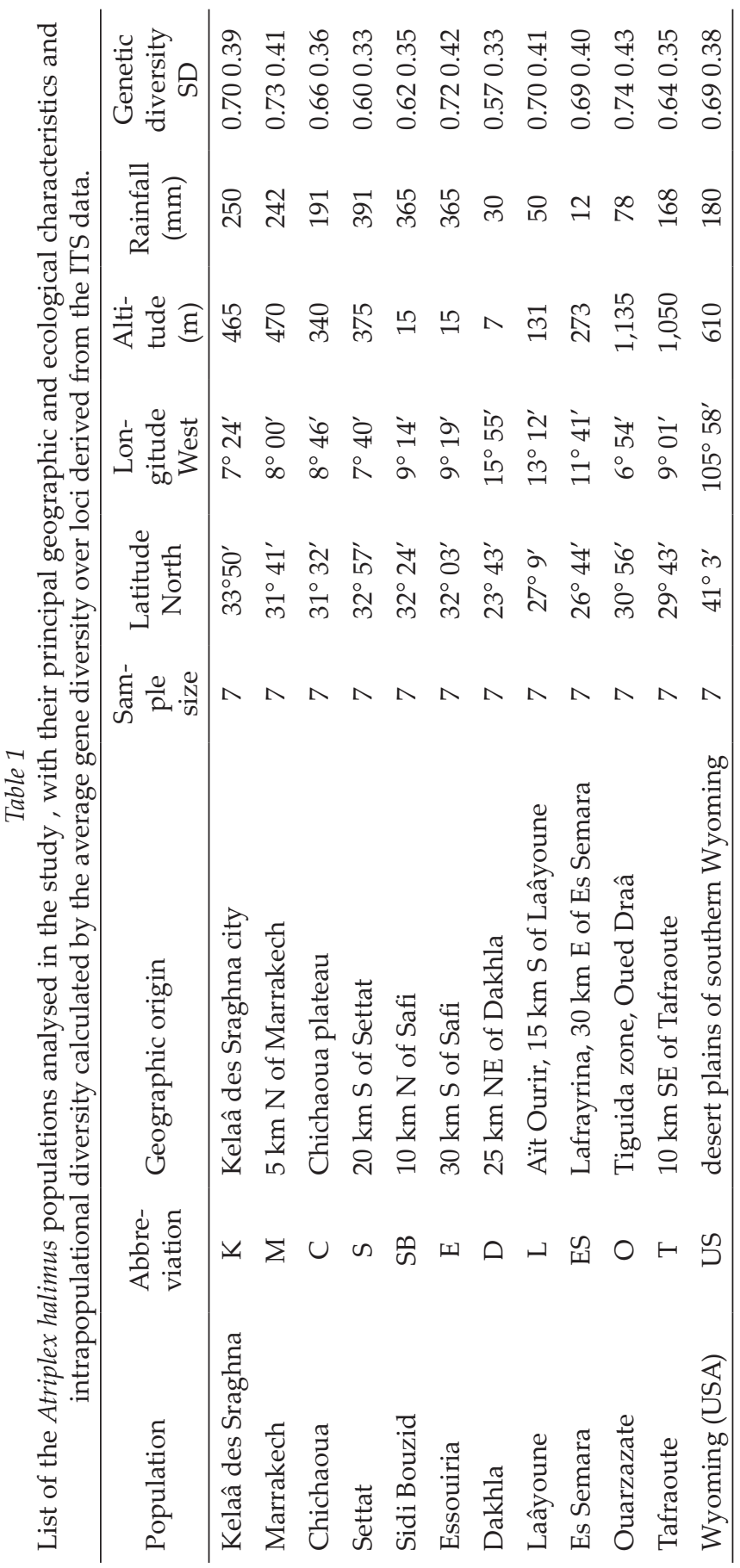


was determined by NanoDrop spectrophotometer (NanoDrop Technologies, Wilmington, USA).

The ITS region was amplified using the primers ITS4 (5'-TCCTCCGCTTATTGATATGC-3') and ITS5 (5'-GGAAGTAAAAGTCGTAACAAGG-3') described by White et al. (1990) in a single reaction. The region includes the two spacers ITS1 (approx. $300 \mathrm{bp}$ ) and ITS2 (approx. $220 \mathrm{bp}$ ), along with the $5.8 \mathrm{~S}$ gene (approx. $160 \mathrm{bp}$ ). The PCR reactions were performed in a volume of 50 $\mu \mathrm{l}$ containing: $40 \mathrm{ng}$ of template DNA, $10 \mathrm{mM} 10 \times$ PCR buffer (supplied with Fideli $^{\mathrm{TM}}$ Taq DNA polymerase), $0.8 \mu \mathrm{M}$ of each primer, $0.4 \mathrm{mM}$ dNTPs, $1 \mathrm{mM}$ $\mathrm{MgCl}_{2}$, and $1 \mathrm{U}$ of Fideli ${ }^{\mathrm{TM}} \mathrm{Taq}$ DNA polymerase (USB Corporation, USA). Amplifications were conducted in Techgene (TECHNE, Cambridge, UK) thermal cycler through 45 cycles of $94{ }^{\circ} \mathrm{C}$ for $2 \mathrm{~min}, 50{ }^{\circ} \mathrm{C}$ for $30 \mathrm{sec}$ and $68{ }^{\circ} \mathrm{C}$ for $1 \mathrm{~min}$. Successful PCR amplification produced a single band of approx. 750 bp. The amplicons were purified using the GFX PCR DNA purification kit (GE-Healthcare). DNA concentration of purified PCR products was estimated on agarose gel by comparing the fluorescent yield of the sample with that of known amounts of $1 \mathrm{~kb}$ DNA ladder bands on densitometry KODAK 1D image Analysis Software (Sambrook et al. 1989). The purified products were sequenced in the sense and antisense directions, using the same primers utilised for PCR (ITS4 and ITS5). Sequencing was done in the Genomic Service of Universidad Autónoma de Madrid (Spain) by using multicapillary Sequencer ABI Prism 3730 DNA Analyser (Applied Biosystems, USA).

\section{Data analyses}

Nucleotide sequences obtained were proofread, and contiguous sequences generated using the SeqMan v. 4.03, and then compiled into EditSeq v. 4.03 , being both programs parts of the DNASTAR software package (LASERGEN, USA). Blast searches confirmed that our products belonged to the Atriplex halimus species. The ITS sequences obtained have been deposited in the NCBI database with the accession numbers from KX274787 to KX274869. Genetic distances among populations were calculated according to Kimura's 2-parameters model (Kimura 1980). The genetic distances matrix obtained was then used to construct a dendrogram using the Neighbour-joining method (Saitou and Nei 1987). Reliability of the branches was assessed by bootstrapping the data with 2,000 replicates. Atriplex prostrata (GenBank accession AY873931) has been chosen as out-group. Both last analyses were done by MEGA program, version 3.1 (Kumar et al. 2004).

Partition of the observed ITS variation and calculation of the corresponding F-values were carried out by AMOVA (Excoffier et al. 1992) at three levels. Firstly, AMOVA was done to apportion the total genetic variation into two 
hierarchical levels: among populations $\left(\mathrm{F}_{\mathrm{ST}}\right)$ and within populations. A second AMOVA was carried out to quantify the amount of ITS variation accounting between regional groups of populations (Moroccan region versus American region). To research possible differences between the three main bioclimatic zones (ecological groups: semi-arid, arid and Saharan groups), the populations were gathered according to their bioclimatic zones, and a third AMOVA was realised. The number of pairwise differences between ITS sequences has been taken as genetic distance to run the AMOVA. The pairwise genetic differentiation $\left(\mathrm{F}_{\mathrm{ST}}\right)$ among the 12 populations was also provided by AMOVA. The nucleotide diversity average over loci index was calculated to assess the intra-population variability. The number of permutations significant testing was set up at 2,000 for all analyses. These analyses were done using the package ARLEQUIN version 3.01 (Excoffier et al. 2005). Gene flow (number of migrants per generation $=\mathrm{N}_{\mathrm{e}} \mathrm{m}$ ) was estimated through Wright's island model (1949; Slatkin and Barton 1989) as $\mathrm{N}_{\mathrm{e}} \mathrm{m}=0.25\left(1 / \mathrm{F}_{\mathrm{ST}}-1\right)$. A Mantel test was run to look for significant correlation between matrices of genetic distances $\left(\mathrm{F}_{\mathrm{ST}}\right)$ and geographic distances among populations (1,000 permutations; routine MXCOMP of the NTSYS-pc; package; Rohlf 1998).

\section{RESULTS}

The entire sequence of ITS region, comprising ITS1, 5.8S RNA gene and ITS2 was obtained for 84 individuals, seven from each population. Successful PCR amplification generated a single band of almost $750 \mathrm{bp}$ (Fig. 2).

The results of AMOVA showed $94 \%$ of genetic variation residing within populations and among populations variation accounting only for $6 \%$ (Table $2)$. This low genetic differentiation among the populations $\left(\mathrm{F}_{\mathrm{ST}}=0.06\right)$ is concordant with the high value obtained for the average number of individuals exchanged between populations per generation $\left(\mathrm{N}_{\mathrm{e}} \mathrm{m}=4.0\right)$. Besides, the per-

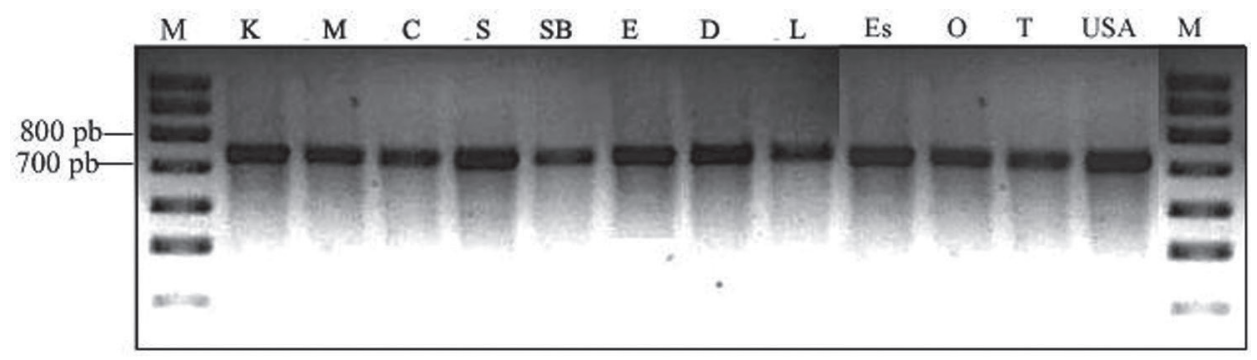

Fig. 2. PCR amplification of $18 S-26 S$ ribosomal DNA ITS region obtained with the primers ITS4 and ITS5 for the twelve Atriplex halimus populations. M, 100 bp ladder marker. Abbreviations as in Table 1 
Table 2

AMOVA analysis of the ITS variation of 12 populations of Atriplex halimus

\begin{tabular}{lccccc}
\hline Source of variation & d.f. & $\begin{array}{c}\text { Sum of } \\
\text { squares }\end{array}$ & $\begin{array}{c}\text { Variance } \\
\text { components }\end{array}$ & $\begin{array}{c}\text { Percentage } \\
\text { of variation }\end{array}$ & F-statistics \\
\hline Global & 11 & $3,840.48$ & 15.53 & 6.03 & $\mathrm{~F}_{\mathrm{ST}}=0.060 \mathrm{NS}$ \\
$\begin{array}{l}\text { Among populations } \\
\text { Within populations }\end{array}$ & 71 & $17,175.84$ & 241.91 & 93.97 & \\
\hline $\begin{array}{l}\text { Hierarchical } \\
\text { Among regional groups }\end{array}$ & 1 & 306.28 & 3.81 & 1.50 & $\mathrm{~F}_{\mathrm{CT}}=0.015 \mathrm{NS}$ \\
$\begin{array}{l}\text { Among populations } \\
\text { within groups }\end{array}$ & 10 & $3,534.20$ & 16.17 & 5.36 & $\mathrm{~F}_{\mathrm{SC}}=0.053 \mathrm{NS}$ \\
Within populations & 71 & $17,175.84$ & 241.91 & 94.14 & $\mathrm{~F}_{\mathrm{ST}}=0.0 .049^{* * *}$ \\
$\begin{array}{l}\text { Among ecological groups } \\
\text { Among populations }\end{array}$ & 2 & 559.23 & 3.15 & 1.23 & $\mathrm{~F}_{\mathrm{CT}}=0.012 \mathrm{NS}$ \\
within groups & 9 & $3,281.25$ & 17.74 & 5.92 & $\mathrm{~F}_{\mathrm{SC}}=0.059 \mathrm{NS}$ \\
Within populations & 71 & $17,175.84$ & 241.91 & 94.31 & $\mathrm{~F}_{\mathrm{ST}}=0.057^{* * *}$ \\
\hline Total & 82 & $21,016.32$ & 254.27 & & \\
\hline
\end{tabular}

*** Highly significant $(\mathrm{P}<0.001)$, NS: non-significant

centage of genetic variation between regions was only $1.50 \%$, implying that there is no significant genetic differentiation of $A$. halimus populations located on opposite sides of the Atlantic Ocean. To identify the source of genetic variation, AMOVA was performed with three ecological groups designated on the basis of bioclimatic type of the population. The results revealed very low genetic differentiation among ecological groups $\left(\mathrm{F}_{\mathrm{CT}}=0.012 ; \mathrm{P}>0.001\right)$, which suggests that there is no sign of local adaptations of studied $A$. halimus populations, by using as markers sequences of nrDNA ITS region.

Genetic distances between Atriplex halimus populations was estimated by using $\mathrm{F}_{\mathrm{ST}}$ values to look for sequences divergence. The pairwise $\mathrm{F}_{\mathrm{ST}}$ values and geographic distances between the 12 populations are presented in Table 3. From a total of 66 made, only 18 pairwise genetic distances $\left(\mathrm{F}_{\mathrm{ST}}\right)$ between populations were significant $(\mathrm{P}<0.01)$. It varied from $0.001(\mathrm{E} / \mathrm{O}, 401 \mathrm{~km})$ to $0.18(\mathrm{~S} / \mathrm{T}, 378 \mathrm{~km})$, indicating that populations Essouiria and Ouarzazate were the most closer each other, and the populations Settat and Tafraout were the most genetically distant at ITS sequences. The matrix of 66 pairwise genetic distances $\left(\mathrm{F}_{\mathrm{ST}}\right)$ among the 12 populations was not significantly associated with their corresponding geographical distances after Mantel test execution $(\mathrm{r}=$ $0.061, t=0.36, p=0.64$. The results of intrapopulational variation of $A$. halimus populations showed low level for USA population, obtained from the orchard 


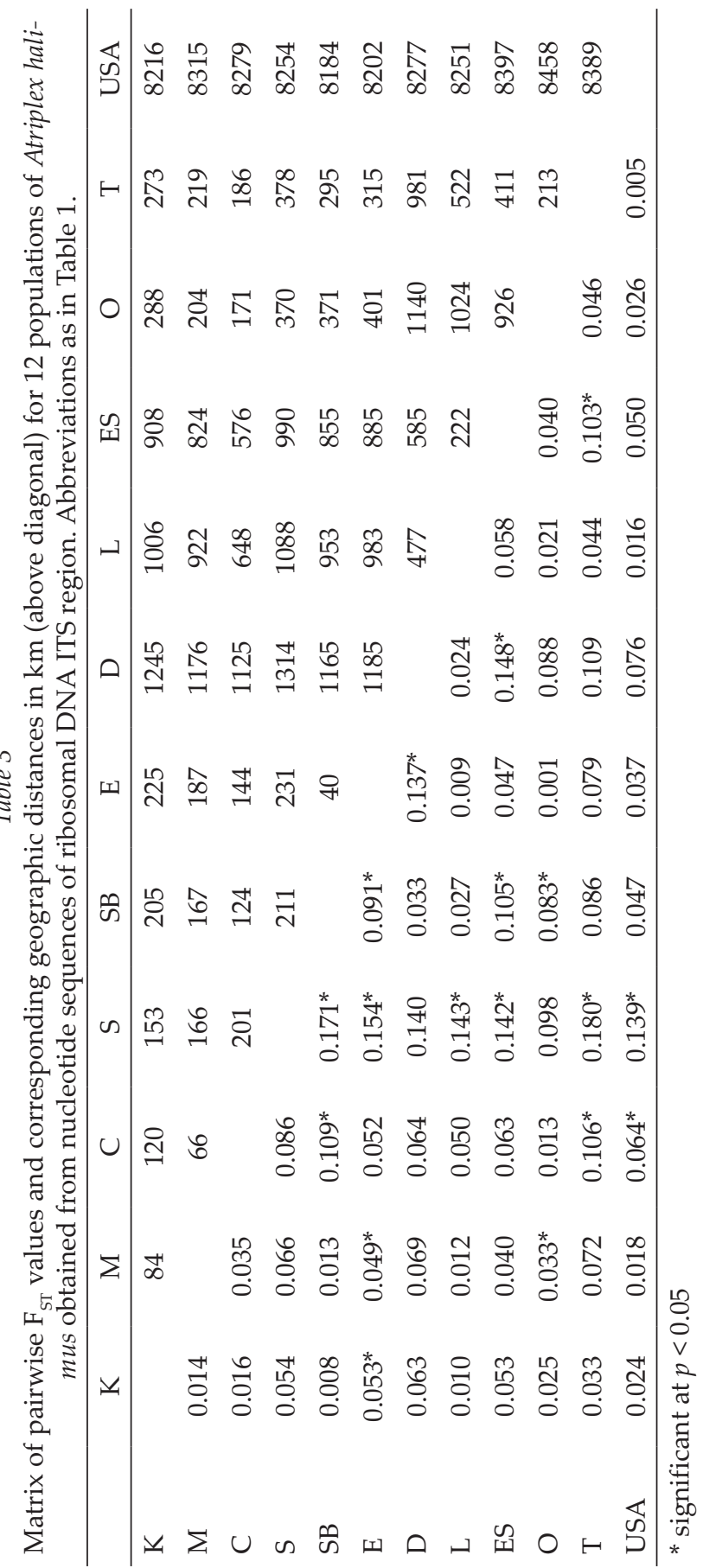

of Khmiss M'touh El Jadida, Morocco (Table $1)$. This is no astonishing since that this population is a recent introduction to the area, its stock plant being kept in the orchard for 21 years. By opposition, the highest variability was registered in Ouarzazate (0.74), Marrakech (0.73) and Essouiria (0.72) populations.

The rooted neighbour-joining tree, based on genetic distances between populations, resulted in five main clusters of $A$. halimus populations (Fig. 3). The first cluster (I), supported by a bootstrap value of 100, consisted of Kelaâ population of arid zones, Laâyoune and Dakhla populations from Saharan zones and Sidi Bouzid population that belong to semi-arid zones. The second cluster (II), with also $100 \%$ bootstrap support, is composed of three populations: Settat of semiarid zones, Chichaoua of arid-zones and Ouarzazate of Saharan zones. The third cluster (III), which received also a high support $(100 \%$ 
bootstrap value), includes the Tafraout and USA populations stemming from arid zones. The fourth cluster (IV), very well supported (100\% bootstrap value) comprised Marrakech population from arid zones and Essouiria population from semi-arid zones; while Es Semara population of Saharan zones was isolated alone to form the fifth cluster (V). Thus, the structuration of $A$. halimus populations in five main groups was not operated according to their bioclimatic type. Furthermore, the Essouiria and Sidi Bouzid populations, collected from the Atlantic littoral, were not gathered even though they are the most geographically closely located populations (40 km apart; see Table 3 ). Thus, genetic relationships among the 12 populations were not compatible with their geographic distances, which are reinforced by the no existence of significant association between genetic and geographic distances, as shown by Mantel test. Besides, the American population was not separated from the rest in the NJ dendrogram, with this corroborating the result of AMOVA, revealing a very low fraction of molecular diversity separating regions (1.5\%).

\section{DISCUSSION}

Evaluation of genetic diversity among and within Atriplex halimus populations plays a crucial role to minimise genetic erosion and to establish efficient strategies for genetic resources conservation in ex-situ and in-situ conditions, as well as to work out the scheme of breeding programs for biomass production and salinity tolerance (Bouda et al. 2008). Different markers were used to assess the genetic diversity in Atriplex halimus at level of Mediterranean Basin (Abbad et al. 2004, Bouda et al. 2008, Elframawy et al. 2016, Had-

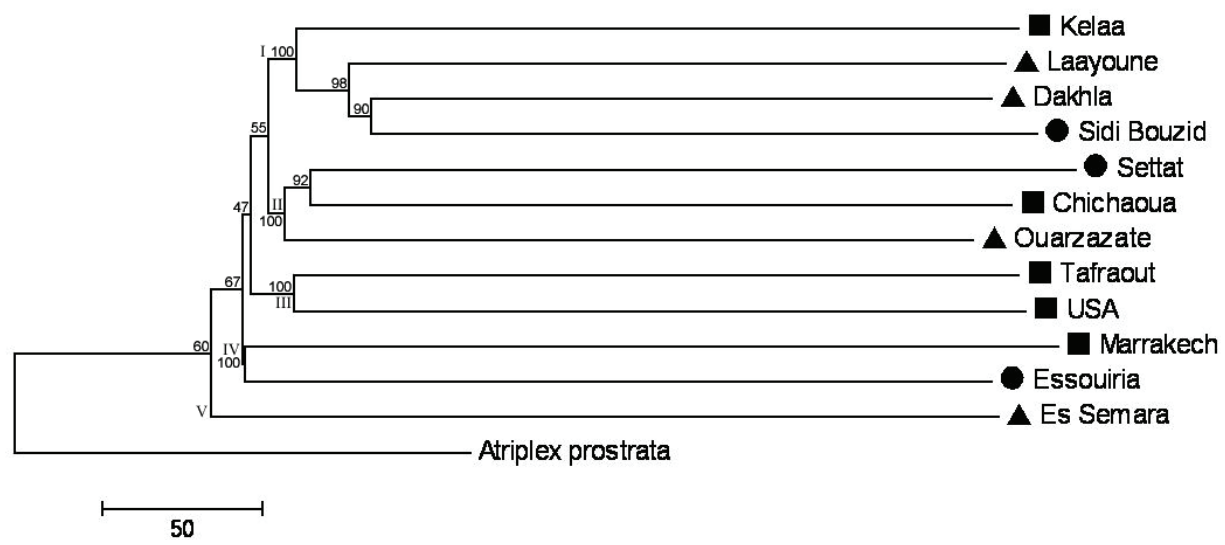

Fig. 3. Phylogenetic tree calculated by neighbour-joining method with 2,000 replicates based on ITS nucleotide sequences in twelve Atriplex halimus populations and out-group Atriplex prostrata (GenBank accession AY873931). Bootstrap values are indicated at nodes 
dioui and Baaziz 2001, Hcini et al. 2006, 2007, 2010, Walker et al. 2005). More recently, Bouda et al. (2013) used RAPDs markers to investigate genetic variability of natural Atriplex halimus populations in Morocco. This study is expanded in the present investigation by using the nucleotide sequences of the entire ITS region of ribosomal DNA.

This study examined twelve populations from different geographic origin in Morocco located in three different climatic contexts: semi-arid bioclimate (Settat, Sidi Bouzid and Essouiria populations), arid bioclimate (Kelaâ des Sraghna, Marrakech, Chichaoua, Tafraout and Wyoming populations) and Saharan bioclimate (Ouarzazate, Laâyoune, Es-Semara and Dakhla populations) using the internal transcribed spacers (ITS), for the purpose of providing additional and valid molecular markers suitable in the examination of the genetic diversity and to assess phenetic relationships in a set of Moroccan Atriplex halimus populations. Genetic diversity of A. halimus in Morocco has been studied only using morphological (Haddioui et al. 2008), isozyme (Haddioui and Baaziz 2001) and RAPD markers (Bouda et al. 2013).

The level and distribution of genetic diversity detected by ITS here are in general agreement with allozyme, RAPD and ITS studies on A. halimus. Haddioui and Baaziz (2001) studied the isoenzyme polymorphism of nine populations of $A$. halimus from several locations in Morocco and found very high intrapopulational diversity compared to others species with the same life history traits (Hamrick et al. 1992, Loveless and Hamrick 1984, Nesbith et al. 1995, Nybom and Bartish 2000). These authors, revealed that genetic diversity of their populations was due mainly to the within population component (92\%). More recently, Bouda et al. (2013) investigated 12 natural populations collected from three bioclimatic zones in Morocco using RAPD markers, and revealed a pattern of greater variation within than between populations of $A$. halimus. By an AMOVA analysis of the RAPD data, they showed that $66.57 \%$ of the genetic diversity were within populations. Furthermore, Elfarmawy et al. (2016) studied six populations from Egypt using ITS and SCoT markers and they have shown that most of the genetic diversity resided within populations (74\%). Likewise, in the current study, Moroccan populations show high polymorphism for ITS at the population level but lower genetic variation between populations. The AMOVA analysis corroborated these findings with the within population variation percentage being $94 \%$ and only $6 \%$ accounting for between populations differences. Plant species differ highly in the way genetic diversity is apportioned between populations and among individuals within population. The pattern of apportioning is related with the mating system and life history traits (Hamrick and Godt 1990). Our results are compatible with the pattern of species that are mainly outcrossing and long-lived pollinated shrub, which held most of their genetic variability within populations, 
whereas selfing species often have low within population diversity and high differentiation among populations (Duminil et al. 2007, Loveless and Hamrick 1984, Nybom 2004, Nybom and Bartish 2000). Therefore, most genetic variation apportioned within population is not astonishing and is possibly due to high level of gene flow at population level. The assessment of gene flow $\mathrm{Nm}$ was about 4.00, which indicates that gene flow among populations was high. This large gene flow could counteract most of the gene differentiation is caused by genetic drift within populations (Slatkin 1985). Genetic differentiation and gene flow are important indices for assessing the population genetic structure of a species. The level of gene flow $(\mathrm{Nm})$ is a key factor that influences the genetic structure and genetic differentiation. The values of genetic differentiation coefficient $\left(\mathrm{F}_{\mathrm{ST}}\right)$ and gene flow $(\mathrm{Nm})$ among these populations of $A$. halimus were 0.06 and 4.00, respectively. Wright (1965) asserted that genetic differentiation was low when the coefficient $\left(\mathrm{F}_{\mathrm{ST}}\right)$ was lower than 0.05 . The movements of genes among populations conceived by the value of gene flow $(\mathrm{Nm})$ is negatively correlated with genetic differentiation, and is basic for population transfer and plant evolution (Slatkin 1985). Previous studies demonstrated that a high rate of gene flow $(>1)$ homogenises the genetic differences among populations, even in the presence of intensive selection and adaptation. It is worth noting that when gene flow among populations is higher than one, it is sufficient to encounter the effects of random drift (Levin 1984). The level of genetic differentiation between populations, revealed in this investigation and earlier allozyme study of our team (Haddioui and Baaziz 2001), was very low, in general, concordant with outcrossing, wind dispersed and wind pollinated woody plant species, especially angiosperms (Hamrick et al. 1992). However, our earlier study (Bouda et al. 2013) analysing the same populations by RAPD markers revealed a strong genetic differentiation $\left(\mathrm{F}_{\mathrm{ST}}=0.33\right)$ among the populations. Furthermore, Ortíz-Dorda et al. (2005) by analysing $51 \mathrm{~A}$. halimus from ten countries in the Mediterranean Basin using RAPD markers, found also a very large genetic differentiation of populations $\left(\mathrm{F}_{\mathrm{ST}}=0.29\right)$. However, due to dominant character of RAPDs, sampling diploid tissue may lead to slight bias in genetic parameters estimates (Isabel et al. 1999, Szmidt et al. 1996).

As known from former investigations, genetic differentiation among populations is strongly influenced by ecological factors (Kölliker et al. 1998, Nevo and Beiles 1989, Nevo et al. 1988). The ecotypic development of populations depends on climatic and edaphic conditions (Nevo et al. 1988) and differences among populations referring to these factors can cause geographic differentiation (Hamrick and Allard 1972, Huang et al. 2013, Nevo et al. 1994, Owuor et al. 1997). Considering these facts, ectopic differentiation among the populations of $A$. halimus, which grew in different habitats under various eco- 
logical conditions could not have been assumed. The results of AMOVA did not give evidence for the ecotypic differentiation among populations from different bioclimatic type since only $1.23 \%$ of the ITS variation was revealed among ecological groups of $A$. halimus populations. Similarly, Elframawy et al. (2016), studying genetic variation of fragmented populations of A. halimus arising from contrasting geographical origins by using SCoT and ITS markers, reported that the soil factors had no effect on population's structure and there were no local adaptation of studied populations. Further, high level of genetic similarity of ITS nucleotide sequences was evidenced among ecologically different habitats for Colobanthus quitensis (Kunth) Bartl (Gianoli et al. 2004), cyanobacteria Prochlorococcus and Synechococcus (Rocap et al. 2002) and Pyrenophora semineperda (Boose et al. 2011). In contrast, strong ITS sequence differentiation between populations living in different environmental habitats was found for Artemisia halodendron Turz. (Huang et al. 2013), Allium wallichii Kunth (Huang et al. 2014), Oxytropis campestris and Oxytropis arctica (Jorgensen et al. 2003) and even for lichen-forming ascomycete Xanthoria parietina (Lindblom and Ekman 2006). Furthermore, despite colonising ecologically differing habitats, the structuration of A. halimus populations in five main groups was independent of their bioclimatic type. This distribution on the phylogenetic tree can be explained by the existence of a broad common genetic basis between the various populations, or the adaptation of the A. halimus populations to ecologically different habitats is not related to the investigated ITS markers. There have been few reports of association between rDNA variation in plants, and environmental and ecological variables. Nevertheless, Flavell et al. (1986) showed that patterns of length variation in the IGS of Triticum dicoccoides rDNA were significantly correlated with environmental factors relating to water availability. Further, Noble et al. (1992) reported that rDNA variation and its association with environmental variation are complex and sitedependent for population differentiation in Salicornia L. More recently, Salim and Gerton (2019) reviewed the role of rDNA in adaptation to environment; they stated that rDNA is particularly sensitive to genomic stresses and acts as a source of adaptive response by changes in copy number. However, Reisch et al. (2003) detecting a certain genetic differentiation among populations of Sesleria albicans Kit. ex Schultes, stated that the detected differentiation level is not related to the investigated RAPD loci.

Genetic distances among populations varied from 0.001 to 0.180 , which shows a wide genetic variability in the studied populations of $A$. halimus throughout the whole distribution area. This high polymorphism is reflecting high historic genetic variability and it is not surprising, since its level depends strongly on plant's life history traits (Hamrick and Godt 1990, Nybom and Bartish 2000). A. halimus is a perennial, allogamous plant species with 
very broad ecological amplitude and these biological characteristics all contribute to create and maintain the observed high level of genetic variability. Besides, A. halimus is a polyploid species; and according to Soltis and Soltis (2000), polyploids, both individuals and populations, keep higher levels of heterozygosity than do their diploid progenitors. Moreover, most polyploids are polyphyletic accumulating genetic diversity from multiple progenitor populations. This permit to A. halimus to occupy numerous habitats, which may contribute to their success in nature by its widespread distribution. Genetic differentiation among populations of $A$. halimus were not related to their geographical distances, as evidenced by Mantel Test, suggesting that geographic distances did not influence genetic variation. Similarly, no correlation between geographic and genetic distances has been found in the widespread, long-lived, perennial species Haloxylon ammodendron L. (Sheng et al. 2005), in the short-lived monocarpic forb Gentianella germanica L. (Fischer and Matthies 1998), in the perennial forb Lychnis viscaria L. (Berge et al. 1998) and in the annual widespread heterocarpic Atriplex tatarica L. (Mandák et al. 2005). In opposition, significant association between genetic and geographic interpopulation distances have been found in the long-lived woody perennial species Quercus petraea L. (Bruschi et al. 2003), in the outcrossing woody species Prunus mahaleb L. (Jordano and Godoy 2000) and in the rare perennial Tradescantia hirsuticaulis L. (Godt and Hamrick 1993). All these case studies are compatible with the view that a close relationship between geographic and genetic distances (Slatkin 1985) may only be expected if gene flow preventing isolation by distance is a simple function of geographical distance and if such gene flow is not overlaid by strong effects of genetic drift. The absence of such relation therefore suggests an important role for gene flow in A. halimus, in line with the observed weak differentiation among populations.

Such results confirm that variation observed among the A. halimus populations using ITS markers did not follow a geographical pattern. The results indicated that gene flow was the principal factor affecting genetic differentiation among populations. Nevertheless, it could be possible that there was a genetic differentiation among ecological groups of populations which is not linked to the ITS markers. The high level of variation found within populations implies that sampling from a few populations, particularly those most variable, for either breeding or conservation could maintain a very large proportion of the variation within the species. To obtain detailed genetic information facilitating the conservation and management of rangelands containing A. halimus, wide ranging and fine scale analysis using molecular markers related to the adaptation to habitat conditions will be required in future studies. 
Acknowledgements - We thank Centre de Production des Semences Pastorales, El Jadida, Morocco, for the supply of USA population seeds. This work has been funded by SpanishMoroccan Interuniversity Cooperation Program through projects 36/04/P/E and A/2387/05 funded by "Agencia Española de Cooperación Internacional"

\section{REFERENCES}

Abbad, A., Cherkaoui, M., Wahid, N., El Hadrami, A. and Benchaabane, A. (2004): Variabilité phénotypique et génétique de trois populations naturelles d'Atriplex halimus. - Compt. Rend. Biol. 327: 371-380. https://doi.org/10.1016/j.crvi.2004.01.005

Berge, G., Nordal, I. and Hestmark, G. (1998): The effect of breeding systems and pollination vectors on the genetic variation of small plant populations within an agricultural landscape. - Oikos 81: 17-29. https://doi.org/10.2307/3546463

Boose, D., Harrison, S., Clement, S. and Meyer, S. E. (2011): Population genetic structure of the seed pathogen Pyrenophora semeniperda on Bromus tectorum in western North America. - Mycologia 103(1): 85-93. https://doi.org/10.3852/09-310

Bouda, S., Del Campo, F. F., Haddioui, A., Baaziz, M. and Hernàndez, L. E. (2008): RAPD and ITS-based variability revealed in Atriplex species introduced to semi-arid zones of Morocco. - Sci. Hortic. 118: 172-179. https://doi.org/10.1016/j.scienta.2008.05.033

Bouda, S., Hernandez, L. E., Del Campo, F. F., Baaziz, M. and Haddioui, A. (2013): Variability of natural populations of Atriplex halimus L. in Morocco as investigated by RAPD markers. - Roman. Biotechn. Lett. 18: 8361-8371. https://pdfs.semanticscholar.org/2245 /0ef79a88d8deadd7dbaef53b90edad251ab6.pdf

Boulanouar, B., Chriyaa, A. and Boutouba, A. (1996): Moroccan experience with fodder shrub research and development. - In: Gustave, G., Bounejmate, M. and Nefzaoui, A. (eds): Fodder shrub development in arid and semi-arid zones. Proc of Regional Workshop on Native and Exotic fodder Shrubs in Arid and Semi-Arid Zones, 27 Oct-2 Nov 1996, Hammamet, Tunisia, pp 135 -152.

Bruschi, P., Vedramin, G. G., Bussotti, F. and Grossoni, P. (2003): Morphological and molecular diversity among Italian populations of Quercus petraea (Fagaceae). - Ann. Bot. 91: 707-716. https://doi.org/10.1093/aob/mcg075

Duminil, J., Fineschi, S., Hampe, A., Jordano, P., Salvini, D., Vendramin, G. G. and Petit, R. J. (2007): Can population genetic structure be predicted from life-history traits? Amer. Naturalist 169: 662-672. https://doi.org/10.1086/513490

El-Bakatoushi, R., Alframawy, A. M., Tammam, A., Youssef, D. and El-Sadek, L. (2015): Molecular and physiological mechanisms of heavy metal tolerance in Atriplex halimus. Int. J. Phytoremed. 17: 789-800. https://doi.org/10.1080/15226514.2014.964844

El Ferchichi, H. O., Hcini, K. and Bouzid, S. (2006): Chromosome numbers in Tunisian populations of Atriplex halimus L. (Chenopodiaceae). - Afr. J. Biotechn. 5(12): 1190-1193. https://doi.org/10.5897/AJB06.039

Elframawy, A., Deif, H. and El-Bakatoushi, R. (2016): Genetic variation among fragmented populations of Atriplex halimus L. using start codon targeted (SCoT) and ITS158S-ITS2 region markers. - Amer. J. Mol. Biol. 6: 101-115. https://doi.org/10.4236/ ajmb.2016.62011 
Excoffier, L., Laval, G. and Schneider, S. (2005): Arlequin ver 30: an integrated software for population genetics data analysis. - Evol. Bioinform. 1: 47-50. https://doi. org/10.1177/117693430500100003

Excoffier, L., Smouse, P. E. and Quattro, J. M. (1992): Analysis of molecular variance inferred from metric distances among DNA haplotypes: application to human mitochondrial DNA restriction data. - Genetics 131: 479-491. https://www.ncbi.nlm.nih. gov/pmc/articles/PMC1205020/pdf/ge1312479.pdf

Fischer, M. and Matthies, D. (1998): RAPD variation in relation to population size and plant fitness in the rare Gentianella germanica (Gentianaceae). - Amer. J. Bot. 85(6): 811-819. https://doi.org/10.2307/2446416

Foster, S. A., Scott, R. J. and Cresko, W. A. (1998): Nested biological variation and speciation. - Phil. Trans. Roy. Soc. Lond., Biol. Sci. 353: 207-218. https://doi.org/10.1098/ rstb.1998.0203

Flavell, R. B., O'Dell, M., Sharp, P., Nevo, E. and Beiles, A. (1986): Variation in the intergenic spacer of ribosomal DNA of wild wheat, Triticum dicoccoides, in Israel. - Mol. Biol. Evol. 3: 547-558. https://doi.org/10.1093/oxfordjournals.molbev.a040418

Gianoli, E., Inostroza, P., Zúñiga-Feest, A., Reyes-Díaz, M., Cavieres, L. A., Bravo, L. A. and Corcuera, L. J. (2004): Ecotypic differentiation in morphology and cold resistance in populations of Colobanthus quitensis (Caryophyllaceae) from the Andes of Central Chile and the Maritime Antarctic. - Arctic, Antarctic, Alpine Res. 36(4): 484-489. https://doi.org/10.1657/1523-0430(2004)036[0484:edimac]2.0.co;2

Godt, M. J. W. and Hamrick, J. L. (1993): Genetic diversity and population structure in Tradescantia hirsuticaulis (Commelinaceae). - Amer. J. Bot. 80: 959-966. https://doi. org/10.1002/j.1537-2197.1993.tb15318.x

Gunter, L. E., Tuskan, G. A. and Wallschleger, S. D. (1996): Diversity of populations of switchgrass based on RAPD markers. - Crop Sci. 36: 1017-1022. https://doi. org/10.2135/cropsci1996.0011183x003600040034x

Haddioui, A. and Baaziz, M. (2001): Genetic diversity of natural populations of Atriplex halimus L. in Morocco: an isoenzyme-based overview. - Euphytica 121: 99-105. https://doi.org/10.1023/A:1012051222530

Haddioui, A., Ould Mohamed Lemine, M. M., Zinelabidine, L. H., El Hansali, M. and Bouda, S. (2008): Variabilité phénotypique de la phénologie végétative et de la biomasse d'une espèce d'intérêt écologique et économique au Maroc: Atriplex halimus L. Ecol. mediter. 34: 65-272. https://ecologia-mediterranea.univ-avignon.fr/wp-content/ uploads/sites/25/2017/07/Ecologia_mediterranea_2008-34_02.pdf

Hamrick, J. L. and Allard, R. W. (1972): Microgeographical variation in allozyme frequencies in Avena barbata. - Proc. Natl. Acad. Sci. USA 69: 2100-2104. https://doi. org/10.1073/pnas.69.8.2100

Hamrick, J. L. and Godt, M. J. W. (1990): Allozyme diversity in plant species. - In: Brown, A. H. D., Clegg, M. T., Kahler, A. L. and Weir, B. S. (eds): Plant population genetics, breeding, and genetic resources. Sinauer, Sunderland, MA, pp. 43-63.

Hamrick, J. L., Godt, M. J. W. and Sherman-Broyles, S. L. (1992): Factors influencing levels of genetic diversity in woody plant species. - New Forests 6: 95-124. https://doi. org/10.1007/bf00120641

Hcini, K., Walker, D. J., Bouzid, S., Gonzalez, E., Frayssinet, N. and Correal, E. (2006): Determination of ploidy level and nuclear DNA content in Tunisian populations of Atriplex halimus L. - Genet. Resour. Crop Evol. 53: 1-5. https://doi.org/10.1007/s10722005-5806-4 
Hcini, K., Ben Farhat, H., Harzallah, M. and Bouzid, S. (2007): Diversity in natural populations of Atriplex halimus L in Tunisia. - Plant Genet. Resour. Newslett. 149: 34-38. https://www.bioversityinternational.org/fileadmin/PGR/article-issue_149-art_8lang_en.html

Hcini, K., Cenis, J. L., Enrique, C. and Bouzid, S. (2010): Genetic variation of the species Atriplex halimus L. (Chenopodiaceae) using the ITS1-58S-ITS2 region of the ribosomal DNA. - Amer.-Euras. J. Agric. Environ. Sci. 8: 550-555. https://www.idosi.org/ aejaes/jaes8(5)/12.pdf

Huang, D. Q., Li, Q. Q., Zhou, C. J., Zhou, S. D. and He, X. J. (2014): Intraspecific differentiation of Allium wallichii (Amaryllidaceae) inferred from chloroplast DNA and internal transcribed spacer fragments. - J. Syst. Evol. 52(3): 341-354. https://doi. org/10.1111/jse.12050

Huang, W. D., Zhao, X. Y., Li, Y. Q., Zuo, X. A., Feng, J. and Su, N. (2013): ITS sequence analysis of Artemisia halodendron in different habitat gradients. - Sci. Cold Arid Reg. 5(3): 347-352. https://doi.org/10.3724/sp.j.1226.2013.00347

Isabel, N., Beaulieu, J., Thériault, P. and Bousquet, J. (1999): Direct evidence for biased gene diversity estimates from dominant random amplified polymorphic DNA (RAPD) fingerprints. - Mol. Ecol. 8: 477-483. https://doi.org/10.1046/j.1365-294x.1999.00597.x

Jordano, P. and Godoy, J. A. (2000): RAPD variation and population genetic structure in Prunus mahaleb (Rosaceae), an animal-dispersed tree. - Mol. Ecol. 9: 1293-1305. https://doi.org/10.1046/j.1365-294x.2000.01009.x

Jorgensen, J. L., Stehlik, I., Brochmann, C. and Conti, E. (2003): Implication of ITS sequences and RAPD markers for the taxonomy and biogeography of the Oxytropis campestris and O. arctica (Fabaceae) complex in Alaska. - Amer. J. Bot. 90(10): 1470-1480. https:// doi.org/10.3732/ajb.90.10.1470

Kimura, M. (1980): A simple method for estimating evolutionary rate of base substitution through comparative studies of nucleotide sequences. - J. Mol. Evol. 16: 110-120. https://doi.org/10.1007/bf01731581

Kölliker, R., Stadelmann, F. J., Reidy, B. and Nösberger, J. (1998): Fertilization and defoliation frequency affect genetic diversity of Festuca pratensis Huds. in permanent grasslands. - Mol. Ecol. 7: 1557-1567. https://doi.org/10.1046/j.1365-294x.1998.00486.x

Kumar, S., Tamura, K. and Nei, M. (2004): MEGA3: Integrated software for molecular evolutionary genetics analysis and sequence alignment. - Brief. Bioinform. 5: 150-163. https://doi.org/10.1093/bib/5.2.150

Le Houérou, H. N. (1992): The role of saltbushes (Atriplex spp.) in arid land rehabilitation in the Mediterranean Basin: a review. - Agroforest. Syst. 18: 107-148. https://doi. org/10.1007/bf00115408

Le Houérou, H. N. (2000): Utilization of fodder trees and shrubs in the arid and semiarid zones of West Asia and North Africa. - Arid Soil Res. Rehab. 14: 101-135. https://doi. org/10.1080/089030600263058

Levin, D. A. (1984): Immigration in plants: an exercise in the subjunctive. - In: Dirzo, R. and Sarukhan, J. (eds): Perspectives on plant population biology. Sinauer, Sunderland, Massachusetts, USA, pp. 242-260.

Lindblom, L. and Ekman, S. (2006): Genetic variation and population differentiation in the lichen-forming ascomycete Xanthoria parietina on the island Storfosna, central Norway. - Mol. Ecol. 15: 1545-1559. https://doi.org/10.1111/j.1365-294x.2006.02880.x 
Loveless, M. D. and Hamrick, J. L. (1984): Ecological determinants of genetic structure in populations. - Annu. Rev. Ecol. Syst. 15: 65-95. https://doi.org/10.1146/annurev. es.15.110184.000433

Lutts, S., Lefèvre, I., Delpérée, C., Kivits, S., Dechamps, C., Robledo, A. and Correal, E. (2004): Heavy metal accumulation by the halophyte species Mediterranean saltbush. - J. Environ. Qual. 33: 1271-1279. https://doi.org/10.2134/jeq2004.1271

Mandák, B., Bímová, K., Plačková, I., Mahelka, V. and Chrtek, J. (2005): Loss of genetic variation in geographically marginal populations of Atriplex tatarica (Chenopodiaceae). - Ann. Bot. 96: 901-912. https://doi.org/10.1093/aob/mci242

Nesbitt, K. A., Potts, B. M., Vaillancourt, R. E., West, A. K. and Reid, J. B. (1995): Partitioning and distribution of RAPD variation in a forest tree species, Eucalyptus globulus (Myrtaceae). - Heredity 74: 628-637. https://doi.org/10.1038/hdy.1995.86

Nevo, E. and Beiles, A. (1989): Genetic diversity of wild emmer wheat in Israel and Turkey. Structure, evolution and application in breeding. - Theor. Appl. Genet. 77: 421-455. https://doi.org/10.1007/bf00305839

Nevo, E., Beiles, A. and Krugman, T. (1988): Natural selection of allozyme polymorphisms: a microgeographic differentiation in wild emmer wheat (Triticum dicoccoides). Theor. Appl. Genet. 75: 529-538. https://doi.org/10.1007/bf00276761

Nevo, E., Krugman, T. and Beiles, A. (1994): Edaphic natural selection of allozyme polymorphisms in Aegilops peregrina at a Galilee microsite in Israel. - Heredity 72: 109_ 112. https://doi.org/10.1038/hdy.1994.16

Noble, S. M., Davy, A. J. and Oliver, R. P. (1992): Ribosomal DNA variation and population differentiation in Salicornia L. - New Phytol. 122: 553-565. https://doi. org/10.1111/j.1469-8137.1992.tb00085.x

Nybom, H. (2004): Comparison of different nuclear DNA markers for estimating intraspecific genetic diversity in plants. - Mol. Ecol. 13: 1143-1155. https://doi.org/10.1111/ j.1365-294x.2004.02141.x

Nybom, H. and Bartish, I. V. (2000): Effects of life history traits and sampling strategies on genetic diversity estimates obtained with RAPD markers in plants. - Perspect. Plant Ecol. Evol. Syst. 3: 93-164. https://doi.org/10.1078/1433-8319-00006

Ortíz-Dorda, J., Martínez-Mora, C., Correal, E., Simón, B. and Cenis, J. L. (2005): Genetic structure of Atriplex halimus populations in the Mediterranean Basin. - Ann. Bot. 95: 827-834. https://doi.org/10.1093/aob/mci086

Owuor, E. D., Fahima, T., Beiles, A., Korol, A. and Nevo, E. (1997): Population genetic response to microsite ecological stress in barley, Hordeum spontaneum. - Mol. Ecol. 6: 1177-1187. https://doi.org/10.1046/j.1365-294x.1997.00296.x

Poschlod, P., Dannemann, A., Kahmen, S., Melzheimer, V., Biedermann, H., Mengel, C., Neugebauer, K. R. and Pantle, I. (2000): Genes in the landscapes. Changes in the central European land use and its impact on genetic diversity of plants. - Schriftenreihe für Vegetationskunde 32: 111-127.

Reis, M. S. (1996): Dinâmica da movimentação dos alelos: subsídios para conservarção e manejo de populações naturais de plantas. - Brazil. J. Genet. 19: 37-47.

Reisch, C., Poschlod, P. and Wingender, R. (2003): Genetic differentiation among populations of Sesleria albicans Kit. ex Schultes (Poaceae) from ecologically different habitats in central Europe. - Heredity 91: 519-527. https://doi.org/10.1038/sj.hdy.6800350

Rocap, G., Distel, D. L., Waterbury, B. and Chisholm, S. W. (2002): Resolution of Prochlorococcus and Synechococcus ecotypes by using 16S-23S ribosomal DNA internal 
transcribed spacer sequences. - Appl. Environ. Microbiol. 68: 1180-1191. https://doi. org/10.1128/aem.68.3.1180-1191.2002

Rohlf, F. J. (1998): NTSYS-pc: Numerical taxonomy and multivariate analysis system. Version 202. - Applied Biostatistics, New York. https://www.exetersoftware.com/downloads/ ntsysguide21.pdf

Saitou, N. and Nei, M. (1987): The neighbor-joining method: a new method for reconstruction phylogenetic trees. - Mol. Biol. Evol. 4: 406-425. https://doi.org/10.1093/oxfordjournals.molbev.a040454

Salim, D. and Gerton, J. L. (2019): Ribosomal DNA instability and genome adaptability. Chromosome Res. 27: 73-87. https://doi.org/10.1007/s10577-018-9599-7

Sambrook, J., Fritsch, E. F. and Maniatis, T. (1989): Molecular cloning: a laboratory manual. Cold Spring Harbor Laboratory Press, Cold Spring Harbor, New York, 1881 pp.

Sheng, Y., Zheng, W., Pei, K. and Ma, K. (2005): Genetic variation within and among populations of a dominant desert tree Haloxylon ammodendron (Amaranthaceae) in China. - Ann. Bot. 96: 245-252. https://doi.org/10.1093/aob/mci171

Slatkin, M. (1985): Gene flow in natural population. - Annu. Rev. Ecol. Syst. 16: 393-430. https://doi.org/10.1146/annurev.es.16.110185.002141

Slatkin, M. (1994): Gene flow and population structure. - In: Real, L. A. (ed.): Ecological genetics. Princeton University Press, Princeton, NJ, pp. 3-17.

Slatkin, M. and Barton, N. H. (1989): A comparison of three indirect methods for estimating average levels of gene flow. - Evolution 43: 1349-1368. https://doi. org/10.1111/j.1558-5646.1989.tb02587.x

Soltis, P. S. and Soltis, D. E. (2000): The role of genetic and genomic attributes in the success of polyploids. - Proceeds Nat. Acad. Sci. USA 97: 7051-7057. https://doi.org/10.1073/ pnas.97.13.7051

Stringi, L., Accardo, A. and Giambalvo, D. (1994): Breeding and methodology in forage shrubs. - In: Papanastasis, V. and Stringi, L. (eds): Fodder trees and shrubs. CIHEAM, Zaragoza, pp. 13-34. (Cahiers Options Méditerranéennes; n. 4) https://om.ciheam. org/om/pdf/c04/95605242.pdf

Szmidt, A. E., Wang, X. R. and Lu, M. Z. (1996): Empirical assessment of allozyme and RAPD variation in Pinus sylvestris (L.) using haploid tissue analysis. - Heredity 76: 412-420. https://doi.org/10.1038/hdy.1996.59

Walker, D. J., Moñino, I., González, E., Frayssinet, N. and Correal, E. (2005): Determination of ploidy and nuclear DNA content in populations of Atriplex halimus (Chenopodiaceae). - Bot. J. Linn. Soc. 147: 441-448. https://doi.org/10.1111/j.1095-8339.2004.00379.x

White, T. J., Bruns, T. and Taylor, J. (1990): Amplification and direct sequencing of fungal ribosomal RNA genes for phylogenetics. - In: Innis, M. A., Gelfand, D. H., Sninsky, J. J. and White, T. J. (eds): PCR protocols: a guide to methods and applications. Academic Press, San Diego, pp. 315-322.

Wright, S. (1949): The genetical structure of populations. - Ann. Eugenet. 15: 323-354. https://doi.org/10.1111/j.1469-1809.1949.tb02451.x

Wright, S. (1965): Theinterpretation of population structure by F-statistics with special regard to systems of mating. - Evolution 19: 395-420. https://doi.org/10.1111/j.1558-5646.1965. tb01731.x

Zhu, G., Bouharmont, J., Lutts, S. and Kinet, J. M. (2001): Determination of chromosome numbers in Atriplex halimus plants. - Atriplex in vivo 10: 1-4. 